\title{
Problematic issues of qualifying actions encroaching upon persons executing justice or preliminary investigation
}

\author{
Aleksander Nikolayevich Varygin ${ }^{1 *}$, Irina Alekseyevna Efremova $^{1}$, Vladimir Gennadyevich \\ Gromov $^{2}$, Pavel Anatolyevich Matushkin ${ }^{1}$ and Anastasiya Mikhaylovna Shuvalova ${ }^{3}$ \\ ${ }^{1}$ Saratov State Legal Academy, Department of Procuratorial Supervision and Criminology, Saratov, \\ Russia \\ ${ }^{2}$ Chernyshevsky Saratov National Research State University, Department of Criminal, Environmental \\ Law and Criminology, Saratov, Russia \\ ${ }^{3}$ Nizhniy Novgorod Branch of the Saint Petersburg Academy of the Investigative Committee, \\ Department of Criminal Science, Nizhniy Novgorod, Russia
}

\begin{abstract}
A prerequisite for this research is a high public hazard of violent crimes committed against persons executing justice or preliminary investigation since this shakes the foundation of justice and buttress of state power in general. This suggests the need to research the prevention of such crimes using criminal legal methods. The primary goal of the research lies in the analysis of the modern condition and development of relevant proposals to improve the current criminal law of the Russian Federation in terms of regulation of criminal liability for the discussed criminal offenses, which will have a positive effect on their prevention. Research methods: dialectical method of cognition, as well general scientific (analysis and synthesis, induction and deduction, logical, systemic-structural methods) and particular methods of cognition (scientifically statistical, formally legal). The novelty is related to an integrated approach to research the problem of prevention of the discussed offenses and proposals developed on this basis to improve the Russian Federation criminal law, which will increase efficiency in the prevention of these offenses. Results: efficiency of preventing such offenses greatly depends on clear legal regulation of legal norms suggesting criminal liability for committing them. There is a pressing need to complement the Criminal Code of the Russian Federation with new wordings of these elements of crimes and changes that would allow formulating a definitive norm clearly defining the scope of persons affected and adopting a Plenum Decree at this stage for this category of criminal cases, which would clarify the implementation of evaluative categories of the discussed elements of crimes.
\end{abstract}

Keywords: violence, qualification problems, justice, preliminary investigation, prevention

* Corresponding author: efremova005@yandex.ru 


\section{Introduction}

For many years, violent criminality has been one of the most important problems that stir up the state, society, and individual citizens. It has penetrated all spheres of social life. Currently, it is relevant in many countries of the world [1-3], with Russia being no exception. For example, in 2019, as many as 270,300 crimes against persons were officially registered [4, p. 7]. The history of humanity shows that criminality (including violent crimes) occurs when the society is de-organized, unstable, and jammed by social and economic problems [5, p. 22]. Russian society has got used to violence in the family, in the street, and in other spheres. Modern violent crimes include those that are committed against persons executing justice or preliminary investigation. These criminal offenses have a high degree of public hazard since any intervention into their legal activities, in particular, by committing criminal offenses, violates the principle of independent judicial power [6-8] thereby shaking the foundation of justice and buttress of state power in general. The power that cannot guarantee the safety of persons that protect it is a weak power. A similar opinion is expressed also by foreign researchers [9, p. 282]. In this connection, it is important to prevent offenses encroaching upon the life and health of such persons including their relatives.

Statistical data shows a relatively stable share of such crimes in the structure of criminality. For example, in 2000 in Russia, 7 crimes provided for in Article 295 of the RF CC were registered; 5 crimes in 2005; 18 crimes in 2010, and only 2 in 2015; 4 crimes in 2018 and 2 crimes in 2019 [10].

The number of crimes provided for in Article 296 of the Criminal Code of the Russian Federation (RF CC) is much higher. In 2000, 89 such crimes were registered; 68 crimes in 2005; 48 crimes in 2010; 82 in 2018 and 81 in 2019 [10]. For comparison, it should be noted that the number of crimes provided for in Articles 317 and 318 of the RF CC is much higher. For example, there were 200 and 8000 registered crimes over the above period, respectively [10].

Any phenomenon of public life is not random and occurs due to some reasons and conditions, the discussed criminal offenses being no exception. One can talk about a lot of reasons and conditions of crimes provided for in Articles 295 and 296 of the RF CC, including those related to the specific features of personalities of the persons of this category (the level of their professional competence [11, p. 273], corruption intentions [12, p. 91] and some others suggesting their victimity). The presence of a number of reasons and conditions for committing the considered criminal offenses causes the need to develop a range of measures intended to prevent and reduce the criminogenic potential of reasons and conditions for committing them. However, as part of this article, the authors would like to discuss the issues of legal regulation of norms setting out criminal liability for committing violent crimes against the life and health of these persons, since its disadvantages also affect the condition of such actions in the country.

The authors believe that there is insufficient legal regulation of criminal legal norms setting out criminal liability for committing violent crimes against the considered category of persons, which may give rise to their incorrect qualification and thereby reduce the efficiency of their prevention. This proves the need to research the issues related to their criminal legal regulation.

\section{Methods}

This paper uses a dialectical method of cognition, as well as general scientific and particular scientific methods. General scientific methods include analysis and synthesis, induction and deduction. logical, systemic-structural methods. Particular scientific methods include statistical, formal legal, and some other methods. 


\section{Results and discussion}

In the RF CC, violence against persons of the discussed category is related to crimes provided for in Articles 296 and 296 of the Criminal Code, where the legislator establishes criminogenic attributes, singles out a range of victims, and defines criminal punishment for committing these crimes. Their correct criminally legal evaluation is of great importance.

The social hazard of the analyzed criminal offenses is undoubted. However, there is a lot of questions concerning the disposition of these articles in the theory of criminal law. For example, there is no unambiguous approach to understanding the subjects of the criminal legal protection of these actions. Some consider the primary subject of Article 295 as the routine activity of judicial bodies, the supplementary subject as the victim life; the primary subject of Article 296 as the routine activity of administration of justice, the supplementary subject as the health and legal interests of the victim [13, 14, pp. 589, 625]. Others consider the subject of Article 296 as relations ensuring the normal activity of judicial bodies and lawenforcement bodies promoting justice. Yet others consider the subject of Article 296 as life, health, and ownership right of victims as a necessary condition of their normal activity [15, pp. 442, 446, 447]. In general, there are two concepts concerning the subjects of the considered elements of crime, specific benefits, and social relations. A more preferable one is the concept of specific benefits protected by criminal law against criminal offenses with a three-tiered structure of subjects according to the principle of commonality of building the system of the Special Part of the Russian Federation Criminal Code.

There is no unambiguous approach to understanding a victim in these crimes, which is largely caused by the fact that, in constructing legal norms setting legal liability for committing the considered criminal offenses, the Russian legislator uses evaluative categories of "another person participating in executing justice" and "their relatives". This means that law enforcers and scientists ask the following questions resulted from an unambiguous position of the Russian legislator: who are other persons participating in executing justice (only arbitration court assessors or this list is much broader due to the inclusion of all participants in Russian proceedings); who are close persons: in particular, are they relatives only or are they persons who are dear to the victim but are not the victim's relatives?

There are various opinions concerning the structure of the objective aspect of Article 295 of the RF CC. It is referred to truncated [13, p. 625; 16; 17, p. 87], formal [18, p. 678; 19, p. $701]$ or formally material $[20$, p. $687 ; 21$, p. $65 ; 22$, p. 113$]$ elements of crime.

There are various opinions regarding the interpretation of the subjective aspect of the considered elements. Supporters of the formally material approach characterize the subjective aspect of crime using an intentional form of guilt or an indirect type of criminal intent, while they use only a direct type of criminal intent in relation to a criminal attempt $[15$, p. 67]. However, the authors believe that, in terms of the subjective aspect, the considered encroachment is characterized by an intentional form of guilt and is expressed by a direct type of criminal attempt. However, the Russian legislator sets out a purpose of crime as structural attributes of elements of crime provided for in Article 295 RF CC. Since the term defining the purpose of the considered criminal offenses is not disclosed by the Russian legislator and it is not an evaluative category, there are frequently problems in the lawenforcement practice in qualifying this criminal offense, which negatively affects the purposes of criminal law.

Moreover, the authors believe that it is required to set a number of problematic questions related to constructing the elements of researched crimes:

- why does the Russian legislator differentiate, in Article 296, criminal liability based on the victim against which a criminal offense was committed while setting out stricter liability for its commitment towards persons executing justice than for committing the same offense 
against persons that execute preliminary investigation whereas Article 295 provides no such differentiation?

- why does the Russian legislator differentiate, in Article 296, criminal liability whereas Article 295 provides no such differentiation?

- how should law-enforcers qualify actions of the person guilty in committing an offense against the life of persons of the considered category after criminal case investigation or proceedings?

- how should law-enforcers qualify actions of the person guilty in committing an offense against the life of persons of the considered category based on overall dislike of the guilty person towards these persons?

- how should law-enforcers qualify the actions of the person guilty in committing an offense against the life of an investigating authority head, inquiry department head, private prosecutor?

This range of problematic issues related to constructing the elements of researched crimes is not limited by the above issues only, and it is much wider, which gives rise to problems in law-enforcement practice in qualifying the discussed criminal offenses. Therefore, it should be stated that the above underlines once again the imperfection of constructing elements of the considered criminal offenses by the legislator and the need to change them.

\section{Conclusion}

The efficiency of preventing the analyzed criminal offenses greatly depends on clear legal regulation of legal norms suggesting criminal liability for committing them. In this connection, there is a pressing need to complement the RF CC with new wordings of these elements of crimes and changes that would allow formulating a definitive norm clearly defining the scope of persons affected and adopting a Plenum Decree at this stage for this category of criminal cases, which would clarify the implementation of evaluative categories of the discussed elements of crimes.

\section{References}

1. I. Ezeonu, Int. J. Soc. Inq. 1(2), 113-134 (2008)

2. D.L. Rothe, D.O. Friedrichs, Soc. Justice 33(1), 147-161 (2006)

3. H.A. Bloch, G. Geis, Man, crime, and society: The forms of criminal behavior (Random House. New York, 1962)

4. Sostoyanie prestupnosti v Rossii za yanvar-dekabr 2019 goda: statist. sbornik [State of criminality in Russia in January-December, 2019: Statistical book] (Main Information and Analysis Center of the Russian Federation Ministry of Internal Affairs, Moscow, 2020)

5. V. Fox, Vvedenie v kriminologiyu [Introduction to Criminology] (Politizdat, Moscow, 1982)

6. A. Sueur, The foundations of justice, in J. Jowell, C. O'Cinneide (eds.), The Changing Constitution, 209-238 (Oxford University Press, Oxford, 2019). https://doi.org/10.1093/he/9780198806363.003.0008

7. S. Patel, J. Roy. Soc. Med. 113(1), 5-6 (2019). https://doi.org/10.1177/0141076819883868

8. C. Bosire, Political statements and independence of the judiciary article (2020). Accessed on: March 16, 2021. [Online]. Available: https://www.researchgate.net/publication/338773819 
9. B. Belton, Ethn. Racial Stud. 36(2), 282-297 (2013). https://doi.org/10.1080 / 01419870.2012 .676198

10. States of Criminality, Forms 1-F and 1-EGS (2000-2019)

11. B.M. Barry, The future of judging, in How Judges Judge, 273-290 (Taylor \& Francis Ltd., London, 2000). https://doi.org/10.4324/9780429023422-8.

12. G. Brooks, Judicial corruption: magistrates, judges and prosecutors, in Criminal Justice and Corruption, 131-157 (Palgrave Macmillan, Cham, 2019). https://doi.org/10.1007/978-3-030-16038-8_6

13. L.V. Inogamova-Khegay, A.I. Rarog, A.I. Chuchayev, Ugolovnoe pravo Rossii: uchebnik dlya vuzov. Osobennaya chast [Criminal Law in the Russian Federation: reference book. Special Part] (INFRA-M, Moscow, 2008)

14. A.N. Ignatov, Yu.A. Krasikov (eds.), Criminal law of Russia: reference book for universities. Special part (Norma, Moscow, 2005)

15. A.V. Naumov, Ugolovnoe pravo. Osobennaya chast: uchebnik dlya akademicheskogo bakalavriata [Legal law. Special part: reference book for bachelor's program] (Yurayt, Moscow, 2019)

16. A.V. Galakhova (ed.), Prestupleniya protiv pravosudiya [Crimes against justice] (Norma, Moscow, 2005)

17. E.A. Terekhova, Ugolovno-pravovaya okhrana zhizni i zdorovya lits, osushchestvlyayushchikh pravosudie ili predvaritelnoe rassledovanie [Criminal legal protection of life and health of persons executing justice or preliminary investigation]. PhD thesis in Legal Science (Academy of the Prosecutor General's of the Russian Federation, Moscow, 2011)

18. A.I. Chuchayev, Kommentarii k Ugolovnomu kodeksu Rossiiskoi Federatsii (nauchnoprakticheskii) [Comments to the Russian Federation Criminal Code (scientific and practical)] (Prospekt, Moscow, 2019)

19. M.P. Zhuravlev, S.I. Nikulin (eds.), Ugolovnoe pravo. Obshchaya i Osobennaya chasti: uchebnik dlya vuzov [Legal law. General and Special Parts: reference book for universities] (Norma, Moscow, 2014)

20. S.I. Ulezko (ed.), Kommentarii k Ugolovnomu kodeksu Rossiiskoi Federatsii s postateinymi materialami i sudebnoi praktikoi [Comments to the Russian Federation Criminal Code with clause-by-clause materials and legal practice] (MarT, Rostov-onDon, 2002)

21. M.M. Musayev, Posyagatelstvo na zhizn litsa, osushchestvlyayushchego pravosudie ili predvaritel'noe rassledovanie: ugolovno-pravovaya i kriminologicheskaya kharakteristika [Offense against life of persons executing justice or preliminary investigation: criminally legal and criminological characteristics]. $\mathrm{PhD}$ thesis in Legal Science (Daghestan State University, Makhachkala, 2006)

22. O.A. Karmanov, Posyagatelstvo na zhizn litsa, osushchestvlyayushchego pravosudie ili predvaritelnoe rassledovanie (ugolovno-pravovoi analiz) [Offense against life of persons executing justice or preliminary investigation (criminally legal analysis). $\mathrm{PhD}$ thesis in Legal Science (Moscow University of the Ministry of Internal Affairs of Russia, Moscow, 2007) 